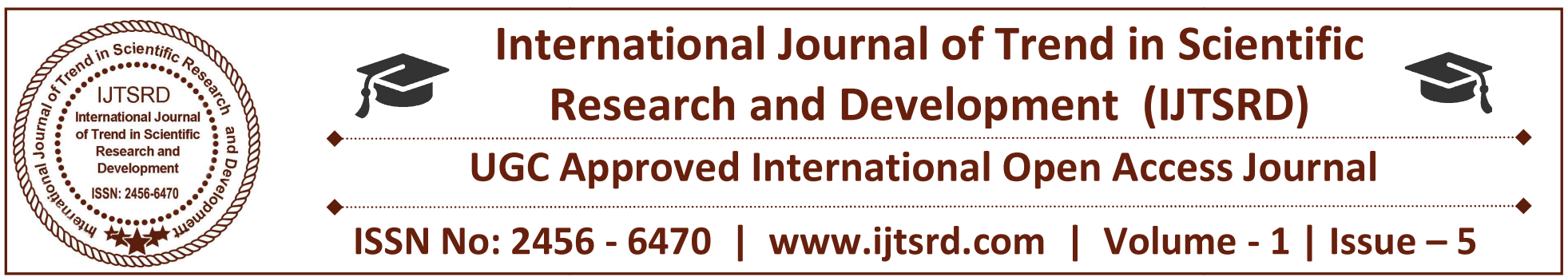

\title{
Challenges Faced in Indian Construction Sector
}

\author{
Danish Shakeel \\ Department of civil engineering, \\ Alfalah University, Dhuaj,Faridabad, India
}

\author{
Zeeshan Khan \\ Department of civil engineering, \\ Alfalah University, Dhuaj,Faridabad, India
}

\section{INTRODUCTION}

\subsection{INTRODUCTION TO INTERNATIONAL CONSTRUCTION SECTOR}

In the year 2011, the European Commission has submitted a communication for the sustainable competitiveness of the construction sector. This study was initiated in 2010 by

European Commission DG Enterprise and Industry, unit G5 "Construction, Pressure Equipment and Metrology" with the purpose of analyzing the needs of the sector as well as the foundation and feasibility of launching a renewed competitive agenda for the EU construction sector within the context of the Smart Growth Agenda 2020.

The point of departure is the 1997 Competitiveness Agenda, presented on 4 November 1997 in the Commission Communication COM (97) 539 "The Competitiveness of the Construction industry". The agenda presented an ambitious plan for improved competitiveness of the construction sector with an extensive list of priority actions. The implementation of the action plan primarily relied on voluntary contributions from sector organizations through 13 working groups established to examine the key challenges and provide recommendations for actions.

The Europe 2020 strategy sets the overarching framework for a future strategy for construction focusing on the following three priorities:

i. Smart growth: developing an economy based on knowledge and innovation; ii. Sustainable growth: promoting a more efficient, greener and more competitive economy;

iii. Inclusive growth: fostering a highemployment economy delivering social and territorial cohesion.

The construction sector is of strategic importance to the EU as it delivers the buildings and infrastructure needed by the rest of the economy and society. It represents more than $10 \%$ of EU GDP and more than $50 \%$ of fixed capital formation. It is the largest single economic activity and it is the biggest industrial employer in Europe. The sector employs directly almost 20 million people. According to FIEC1, the sector indirectly and directly affects some 44 million workers. $40-45 \%$ of Europe's energy consumption stems from buildings with a further $5-10 \%$ being used in processing and transport of construction products and components.

In the medium to long term, infrastructure will have to adapt to future climate risks. Furthermore, the future competitiveness strategy for the construction sector will need to address the environmental and social challenges in the EU and globally. 


\subsection{INTRODUCTION TO INDIAN CONSTRUCTION SECTOR}
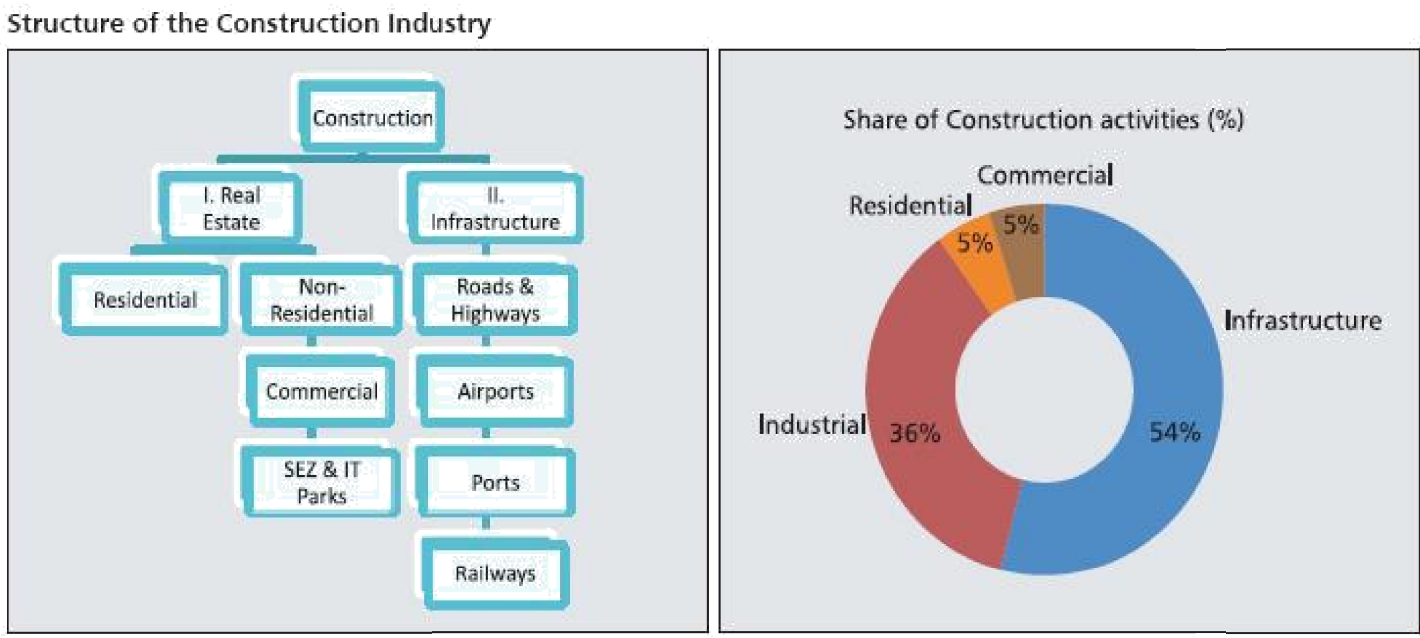

Source: Approach Paper to the Twelfth Five Year Plan, Planning

Source: D\&B Research Commission

\section{Fig.1.1 Structure of the Construction Industry}

In India infrastructure is key to enable economic growth, the government has also committed massive investments of close to USD 500 billion in the infrastructure sector in the Eleventh Plan period (2008 to 2012). The contribution of the construction industry to the GDP has been above 8 per cent since 2007 (Planning Commission, 2011). Over the next decade, India should continue to be among the fastest growing countries in terms of construction output (Accenture $\&$ CIDC, 2012). The total investment in the infrastructure sector during 2012-2017 is estimated to result in construction demand of US\$ 500 billion (ICRA et al., 2011). This plan follows several progressive initiatives taken in recent years, including the Electricity Act 2003, the National Highways Development Project (NHDP), the National Maritime Development Programme (NMDP), and Dedicated
Freight Corridors (DFCs). However, much more needs to be done to accelerate the implementation of infrastructure in India.

India's rapid economic growth over the last decade has placed tremendous stress on its limited infrastructure. The sector has received growing attention from the government and the public, bringing the shortage of infrastructure to the fore. Fulfilling India's aggressive economic growth aspirations would be seriously challenged due to this shortage. The

Country needs to urgently accelerate the conceptualization and implementation of all its infrastructure development to enable planned growth. 


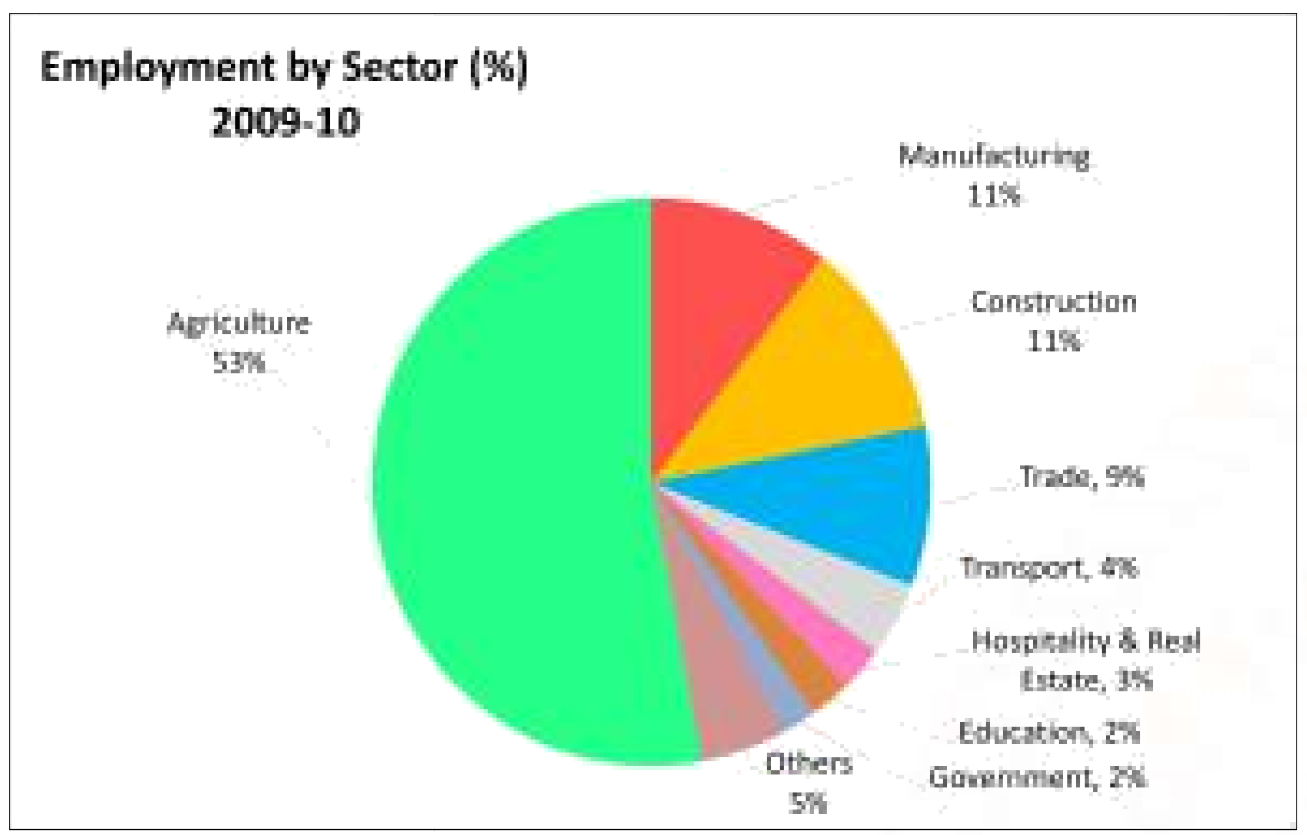

Fig.1.2. Sector wise employment in India.

\subsubsection{IMPEDIMENTS FACED BY THE INDUSTRY}

Construction has been declared as an industry: but has presently no regulatory frame work on an "all India basis". Examples: "national building code" has been evolved \& so also "common general conditions of contract" but have not been Mandated as applicable either by Govt. Of India or any one of the States.

$>$ No common: "construction law" exists.

$>$ No common Regulatory Authority available on Pan India basis, resulting Incompatibility among the Institutions/ Organizations.

$>$ Both service and sales tax are applicable for Construction Industry

$>$ The Construction activities are administered through almost 32 laws, rules and statutes.

$>$ There is no singular nodal agency empowered by the Government to administer the construction activities in the country.

$>$ Regulations not well-defined for the construction industry - residential and commercial buildings, infrastructure projects including roads, ports, harbours and metros

$>$ Clear thoroughfare land availability during tendering stage itself

$>$ Body to monitor roadside encroachments before and after execution
Awareness and lack of knowledge on sustainability

\section{DATA ANALYSIS, INTERPRETATION AND SUGGESTIONS}

\subsection{Questionnaire with response}

Q1: Are you satisfied with the average working hours/ day?

Table 4.1

\begin{tabular}{|c|c|}
\hline \multicolumn{2}{|c|}{ Satisfaction with Average working hours } \\
\hline Rating & Response \\
\hline 1 & 19 \\
\hline 2 & 28 \\
\hline 3 & 34 \\
\hline 4 & 13 \\
\hline 5 & 6 \\
\hline Total & $\mathbf{1 0 0}$ \\
\hline
\end{tabular}



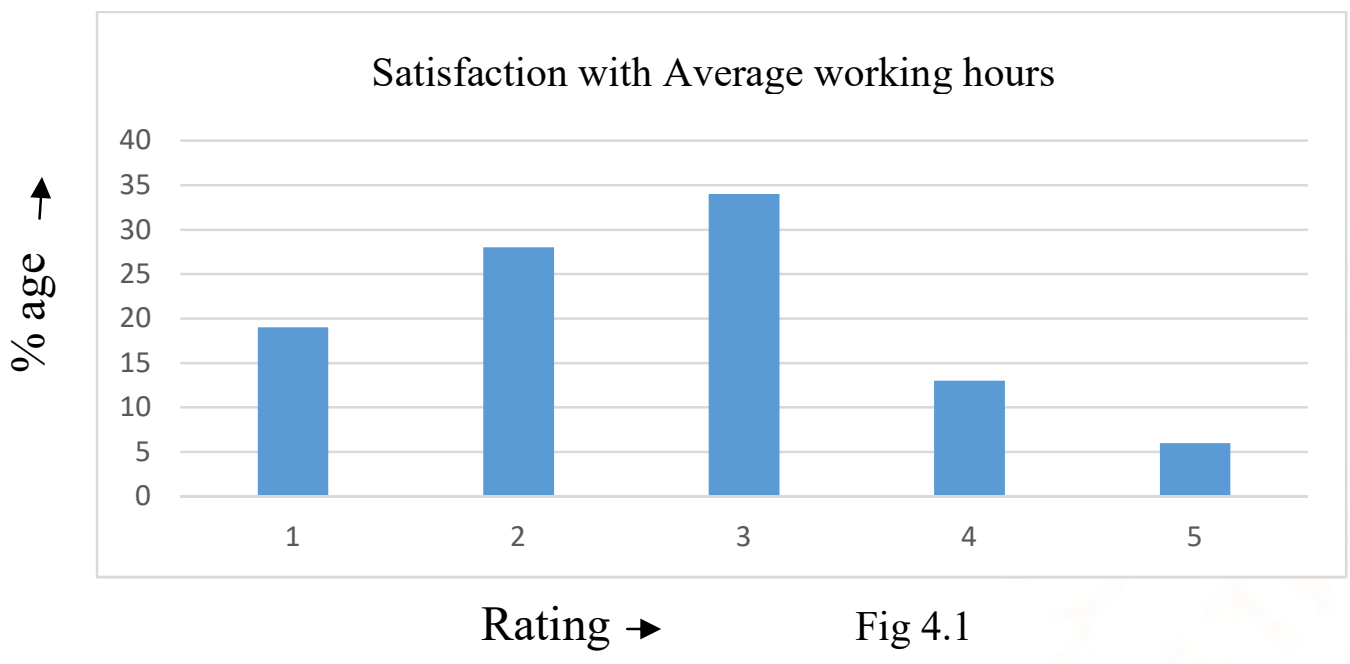

$19 \%$ of the respondents are fully satisfied with their average working hours while $6 \%$ of the respondents are not at all satisfied with their average working hours

\section{Q2: How satisfied are you working for the company on the sites?}

Table 4.2

\begin{tabular}{|c|c|}
\hline \multicolumn{2}{|c|}{ Satisfaction for working on sites } \\
\hline Rating & Response \\
\hline 1 & 10 \\
\hline 2 & 24 \\
\hline 3 & 41 \\
\hline 4 & 16 \\
\hline 5 & 9 \\
\hline Total & 100 \\
\hline
\end{tabular}
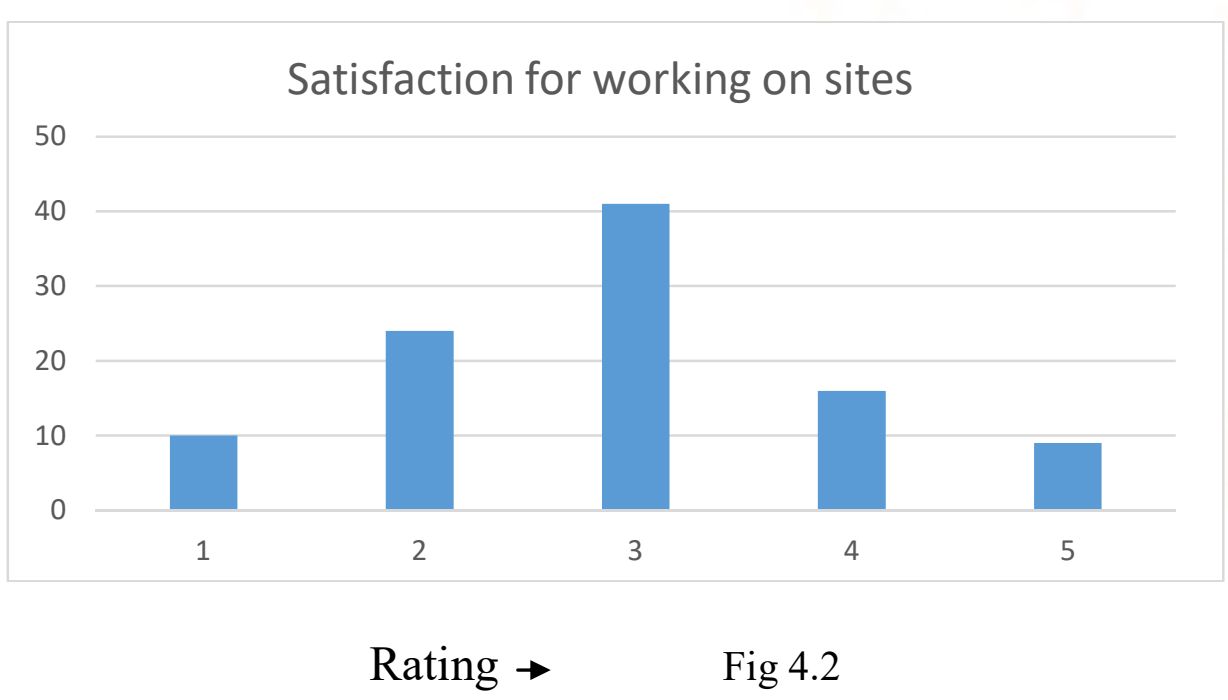

$10 \%$ of the employees are highly satisfied with the working while $41 \%$ of the employees show an average satisfaction level and $9 \%$ employees are not satisfied at all. 
International Journal of Trend in Scientific Research and Development (IJTSRD) ISSN: 2456-6470

Q3: Did you get proper training before the Job?

Table 4.3

\begin{tabular}{|l|l|}
\hline \multicolumn{2}{|c|}{ Getting Proper Training before job } \\
\hline & Response \\
\hline Yes & 42 \\
\hline No & 58 \\
\hline Total & 100 \\
\hline
\end{tabular}

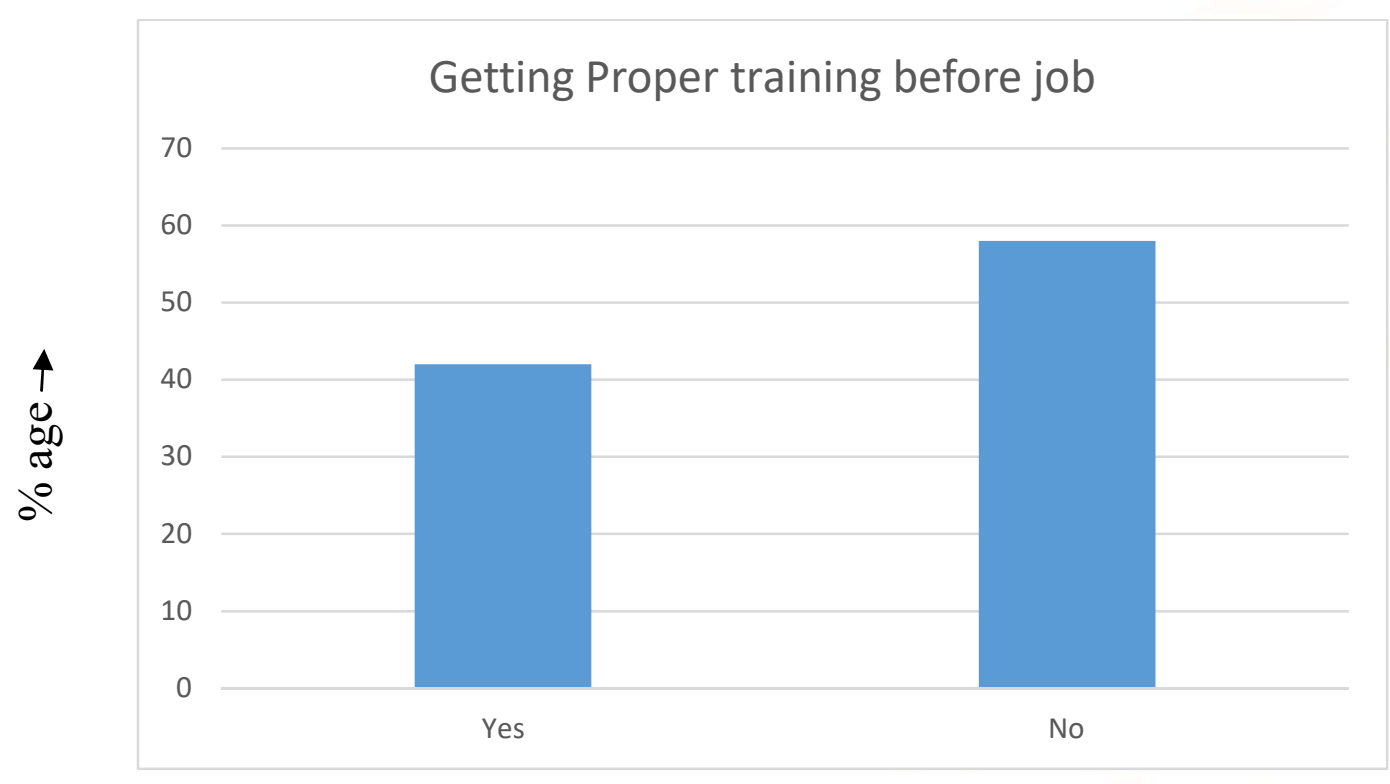

Rating $\rightarrow \quad$ Fig 4.3

$42 \%$ of the respondents did get proper training before the job but $58 \%$ of the respondents did not get the proper job training.

Q4: Do you have right tools to do your job?

Table 4.4

\begin{tabular}{|l|l|}
\hline \multicolumn{2}{|c|}{ Right tools for job } \\
\hline Rating & Response \\
\hline 1 & 17 \\
\hline 2 & 32 \\
\hline 3 & 28 \\
\hline 4 & 12 \\
\hline 5 & 11 \\
\hline Total & 100 \\
\hline
\end{tabular}




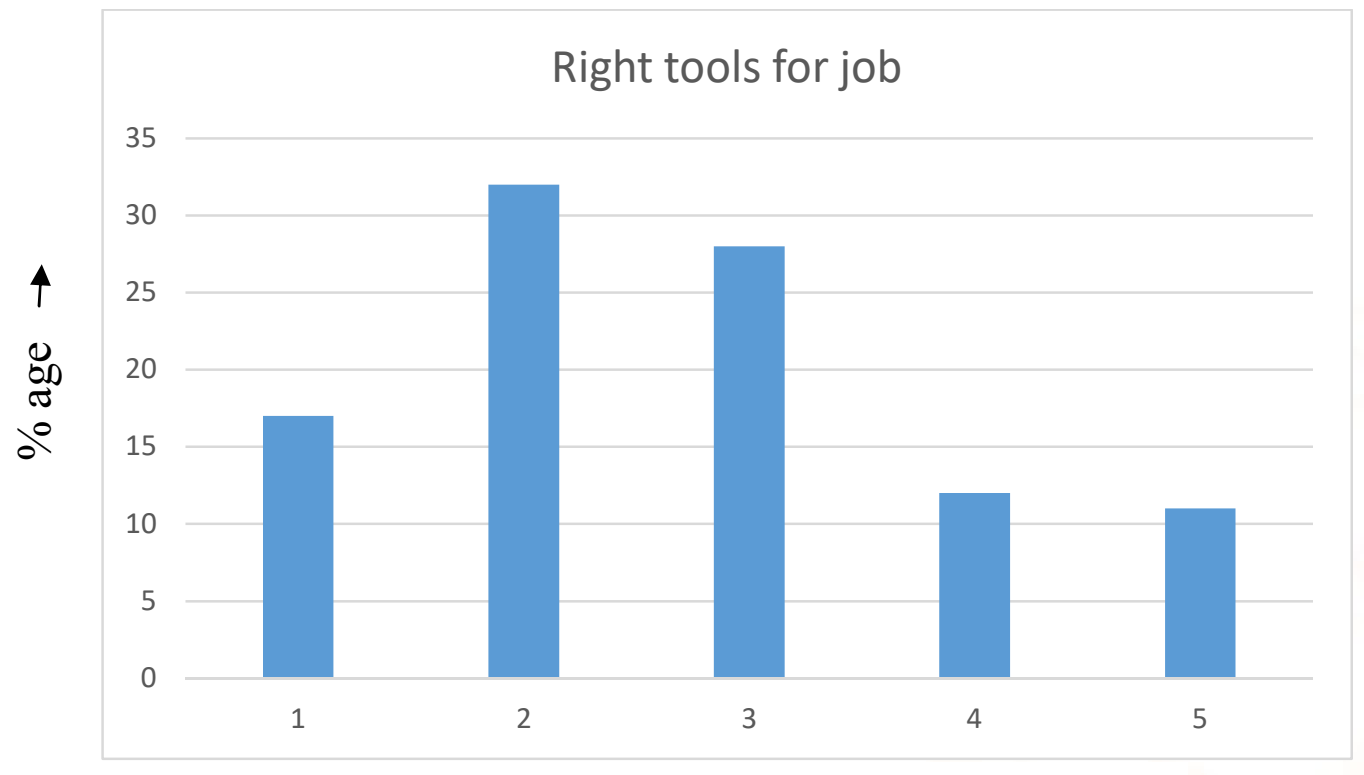

$$
\text { Rating } \rightarrow \quad \text { Fig } 4.4
$$

$17 \%$ of the respondents say they have right tools for the job while $11 \%$ of the respondents say they do not have right tools for the job.

\section{Q5: Is there a good communication between employees to employer?}

Table 4.5

\begin{tabular}{|l|l|}
\hline \multicolumn{2}{|c|}{ Communication between employees and employer } \\
\hline Rating & Response \\
\hline 1 & 14 \\
\hline 2 & 31 \\
\hline 3 & 34 \\
\hline 4 & 14 \\
\hline 5 & 7 \\
\hline Total & 100 \\
\hline
\end{tabular}

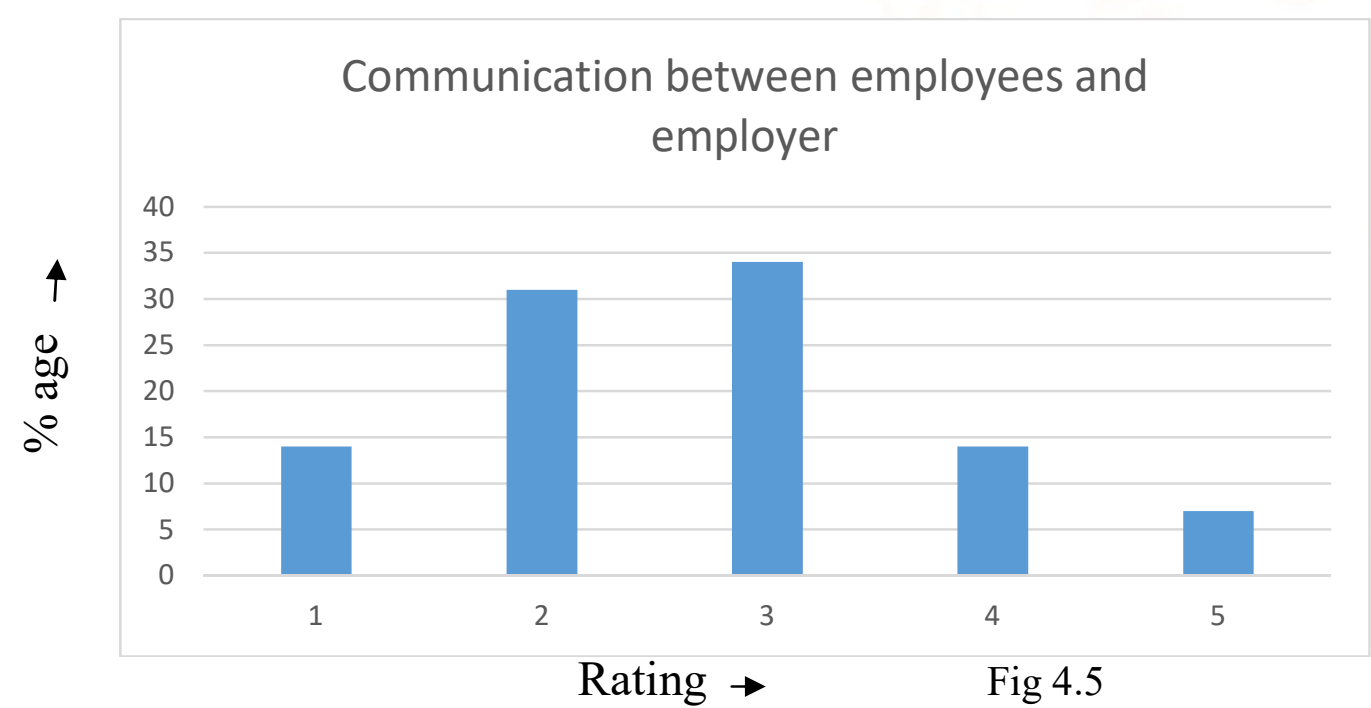

$14 \%$ of the employees agree that there is a good communication between employees and employer while $7 \%$ of the employees say that there is not good communication between employees and employer 
International Journal of Trend in Scientific Research and Development (IJTSRD) ISSN: 2456-6470

and $34 \%$ of the employees agreed that there is average communication between employees and employer.

\section{Q6: Does the disputes of land cause challenge at Construction site?}

Table 4.6

\begin{tabular}{|c|c|}
\hline Disputes of land cause challenge at construction site \\
\hline Rating & Response \\
\hline 1 & 17 \\
\hline 2 & 32 \\
\hline 3 & 33 \\
\hline 4 & 12 \\
\hline 5 & 6 \\
\hline Total & 100 \\
\hline
\end{tabular}

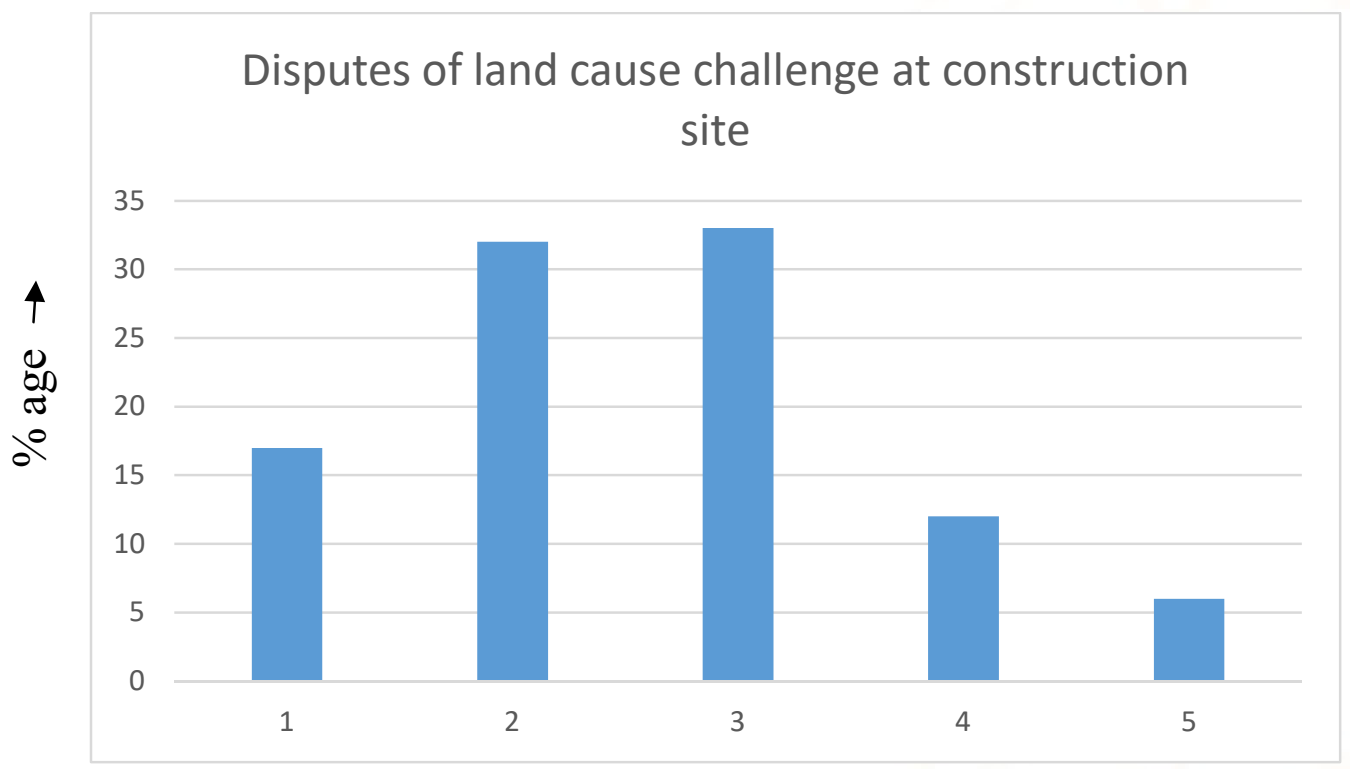

Rating

Fig 4.6

$17 \%$ of the respondents feel that dispute of land is a challenge while $6 \%$ of the respondents feel that it is not a challenge and a majority of $33 \%$ believed that it causes an average challenge at the construction site.

Q7: Do you think that obtaining NOC for construction is a major Challenge?

Table 4.7

\begin{tabular}{|c|c|}
\hline \multicolumn{2}{|c|}{ Obtaining NOC for construction a challenge } \\
\hline Rating & Response \\
\hline 1 & 21 \\
\hline 2 & 23 \\
\hline 3 & 31 \\
\hline 4 & 13 \\
\hline 5 & 14 \\
\hline Total & 102 \\
\hline
\end{tabular}



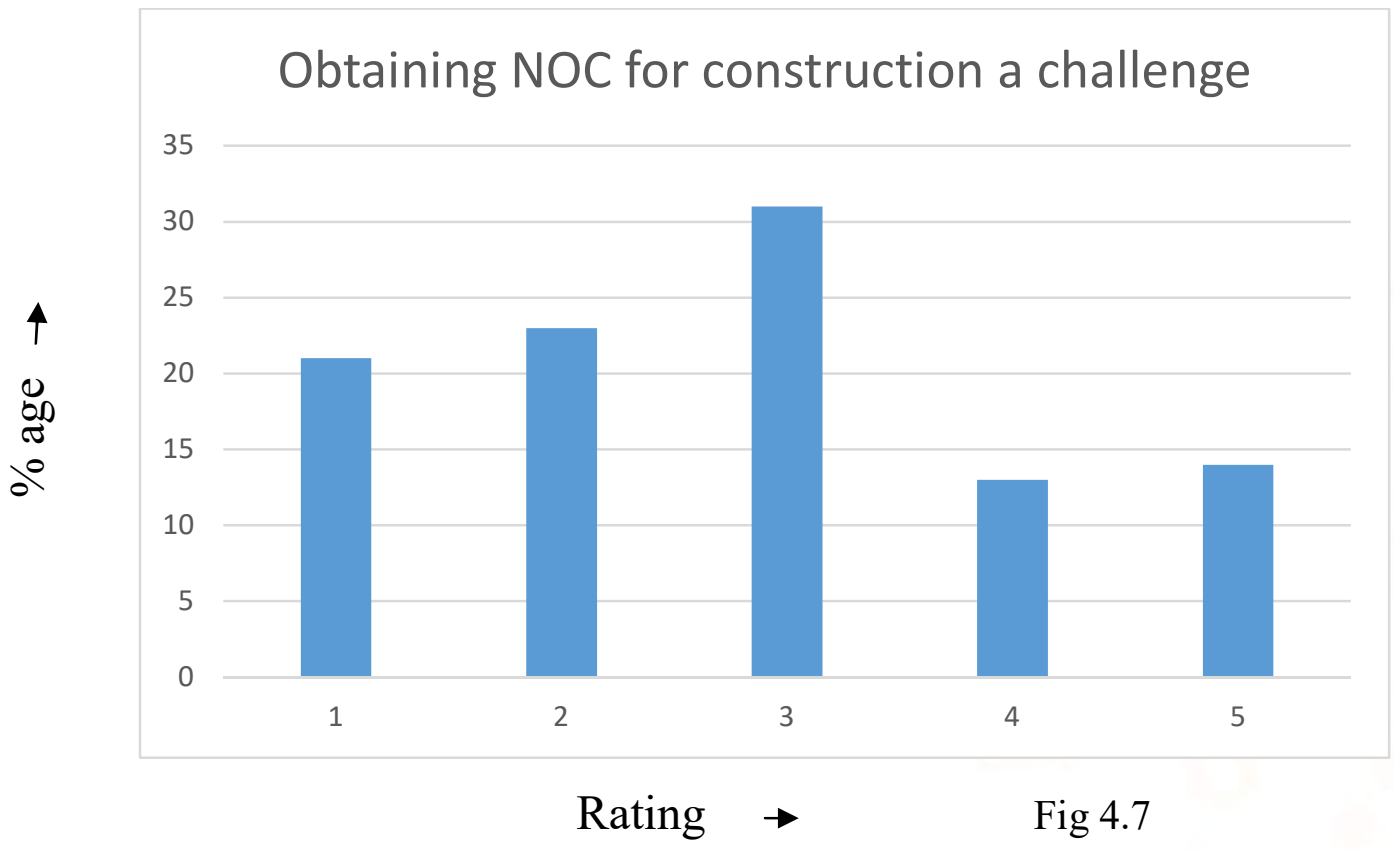

$21 \%$ of the respondents say getting a NOC is a challenge while $14 \%$ of the respondents say getting a NOC is not a challenge and a majority of $31 \%$ believed it to be an average challenge.

\section{Q8: Is there labor scarcity at site?}

Table 4.8

\begin{tabular}{|l|l|}
\hline & Response \\
\hline Yes & 34 \\
\hline No & 66 \\
\hline Total & 100 \\
\hline
\end{tabular}
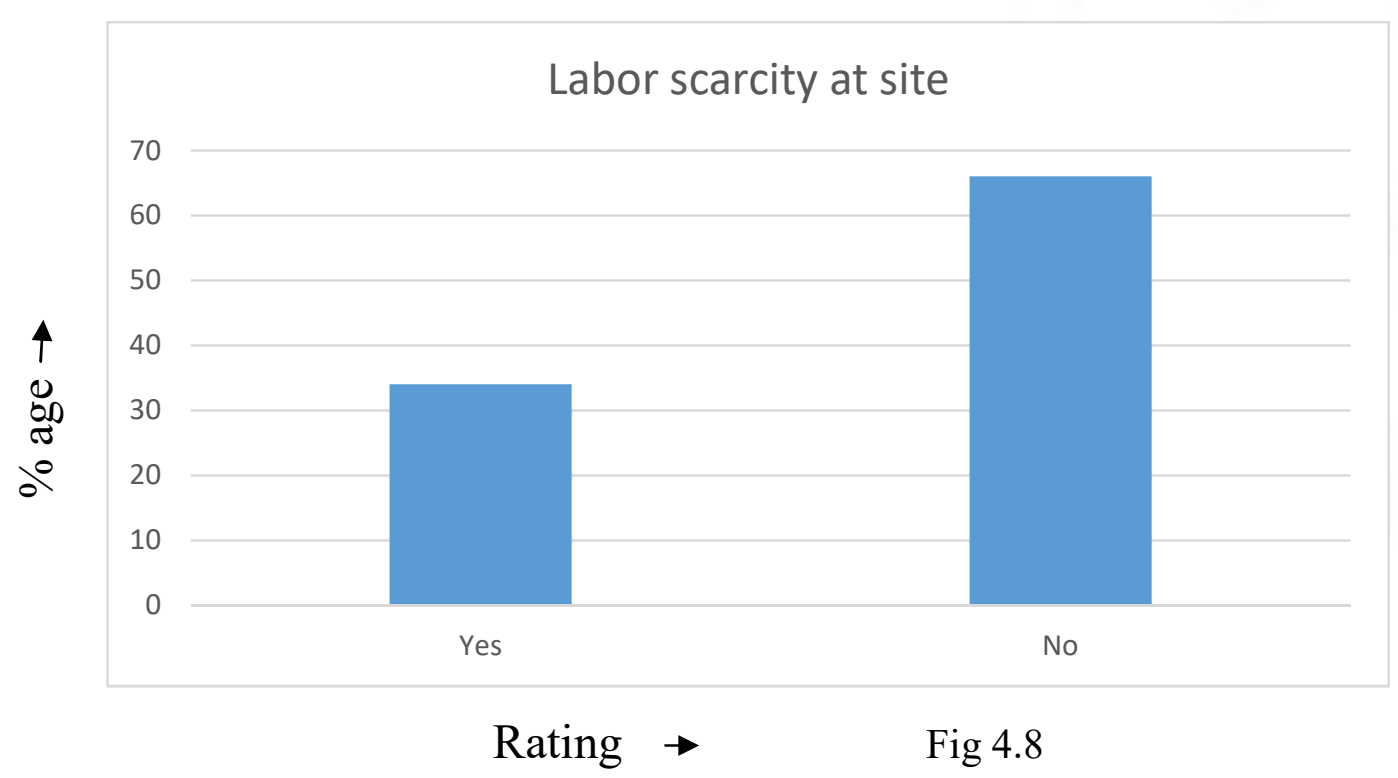

Only $36 \%$ of the respondents agree that there is labour scarcity at site while $64 \%$ of the respondents say there is not labour scarcity 
International Journal of Trend in Scientific Research and Development (IJTSRD) ISSN: 2456-6470

Q9: What factors are responsible for labor scarcity at the site of construction?

Table 4.9

\begin{tabular}{|c|c|c|}
\hline \multicolumn{2}{|c|}{ Factors responsible for labor scarcity } \\
\hline A & Poor Salary & 51 \\
\hline B & $\begin{array}{l}\text { Skilled labor } \\
\text { unavailabilty }\end{array}$ & 10 \\
\hline C & Competition & 26 \\
\hline D & Excess demand & 13 \\
\hline Total & & 100 \\
\hline
\end{tabular}

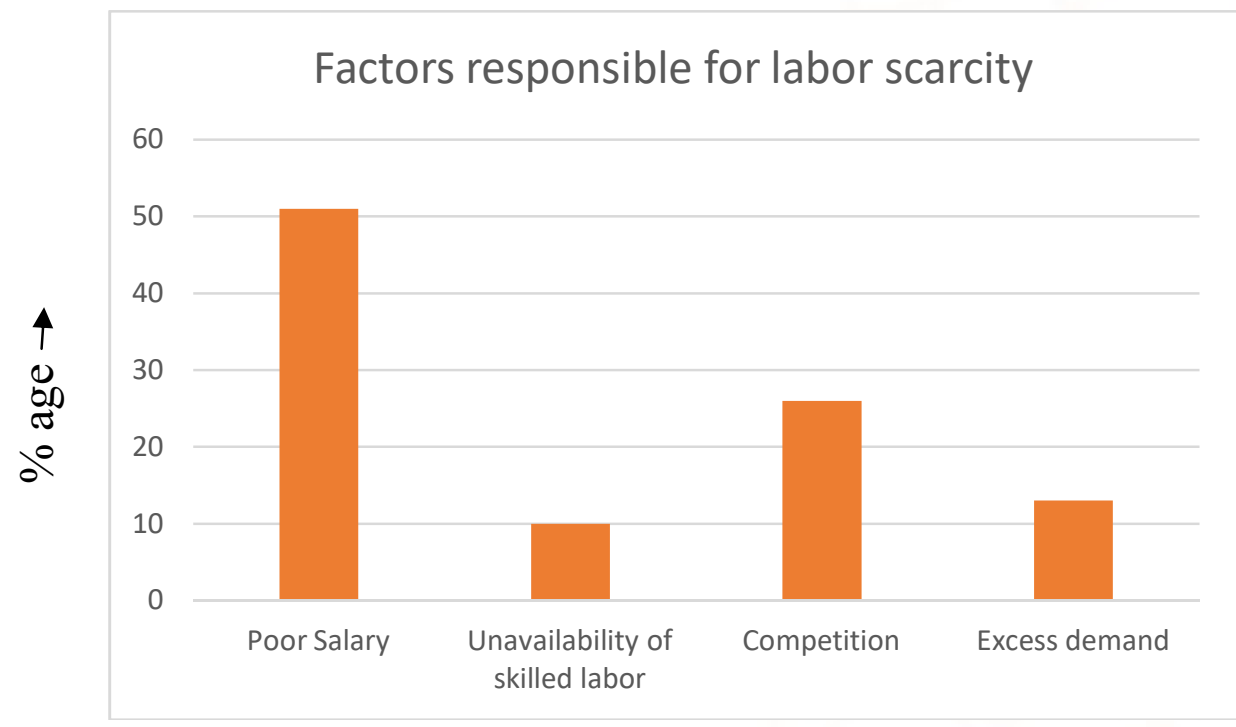

\section{Rating $\rightarrow \quad$ Fig 4.9}

$51 \%$ of the respondents believe that the labour scarcity is because of poor salary, $10 \%$ say it is because of unavailability of skilled labours, $26 \%$ of the respondents say it is because of the competition and 13 $\%$ of the respondents say labour scarcity is because of excess demand.

\section{Q10. Does intermittent nature of work affect labor scarcity?}

Table 4.10

\begin{tabular}{|l|l|}
\hline \multicolumn{2}{|c|}{ Effect of intermittent nature of work on labor scarcity } \\
\hline Rating & Response \\
\hline 1 & 14 \\
\hline 2 & 24 \\
\hline 3 & 26 \\
\hline 4 & 16 \\
\hline 5 & 20 \\
\hline Total & 100 \\
\hline
\end{tabular}




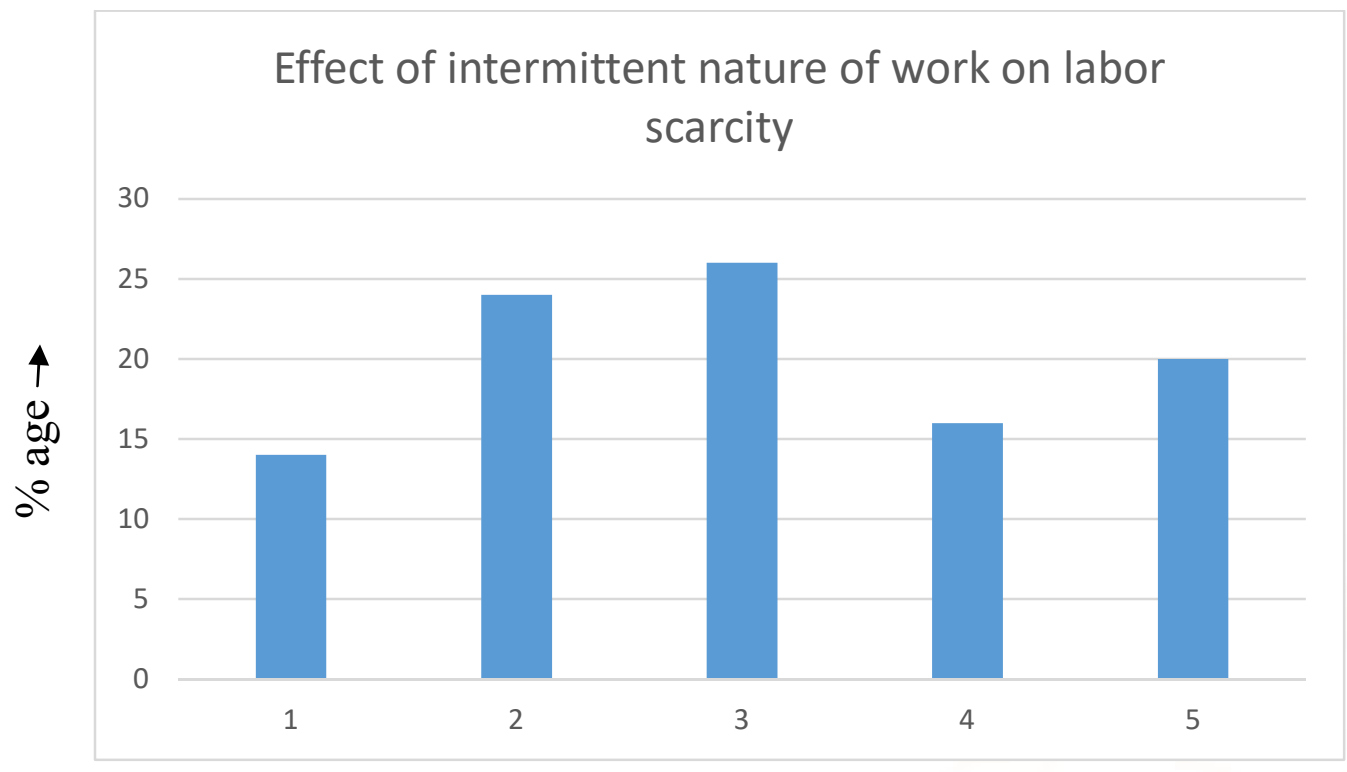

\section{Rating $\rightarrow \quad$ Fig.4.10}

- $14 \%$ of the respondents agreed that intermittent nature of work causes labor scarcity while a majority of $26 \%$ had an average opinion over it and $20 \%$ didn't agree on it.

\section{Q11: Do you agree that changing government policies cause hindrance in Construction sector?}

Table 4.11

\begin{tabular}{|l|l|}
\hline \multicolumn{2}{|c|}{ Hindrance in construction sector by changing construction policies } \\
\hline Rating & Response \\
\hline 1 & 15 \\
\hline 2 & 30 \\
\hline 3 & 32 \\
\hline 4 & 14 \\
\hline 5 & 9 \\
\hline Total & 100 \\
\hline
\end{tabular}

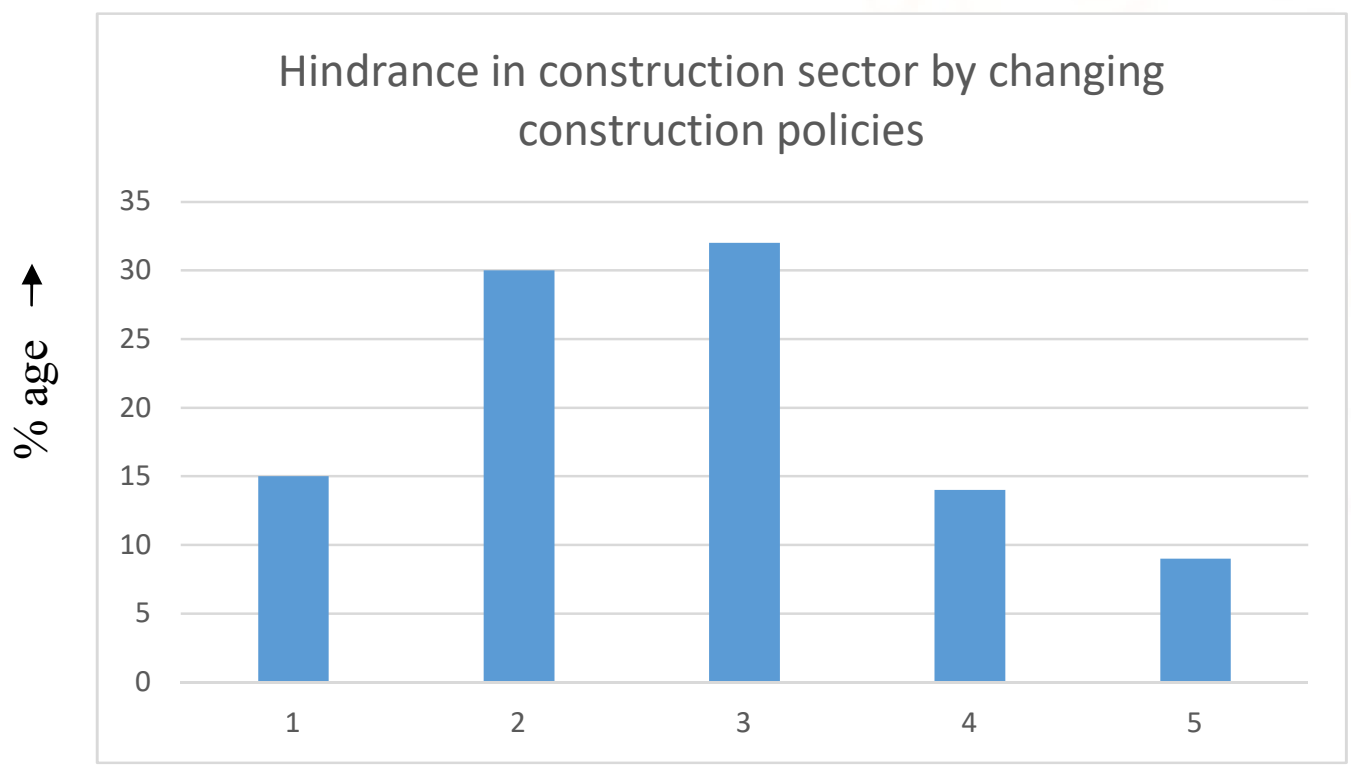

Rating

Fig 4.11 
International Journal of Trend in Scientific Research and Development (IJTSRD) ISSN: 2456-6470

$15 \%$ of the respondents agree that the changing government policies cause hindrance in Construction Sector while $9 \%$ of the respondents do not think so and an average of $32 \%$ had an average opinion.

\section{Q12: Do you think that natural forces are a major Challenge for construction industry?}

Table 4.12

\begin{tabular}{|c|c|}
\hline \multicolumn{2}{|c|}{ Natural forces as a major challenge for construction industry } \\
\hline Rating & Response \\
\hline 1 & 16 \\
\hline 2 & 28 \\
\hline 3 & 27 \\
\hline 4 & 14 \\
\hline 5 & 15 \\
\hline Total & 100 \\
\hline
\end{tabular}

Natural forces as a major challenge for construction industry

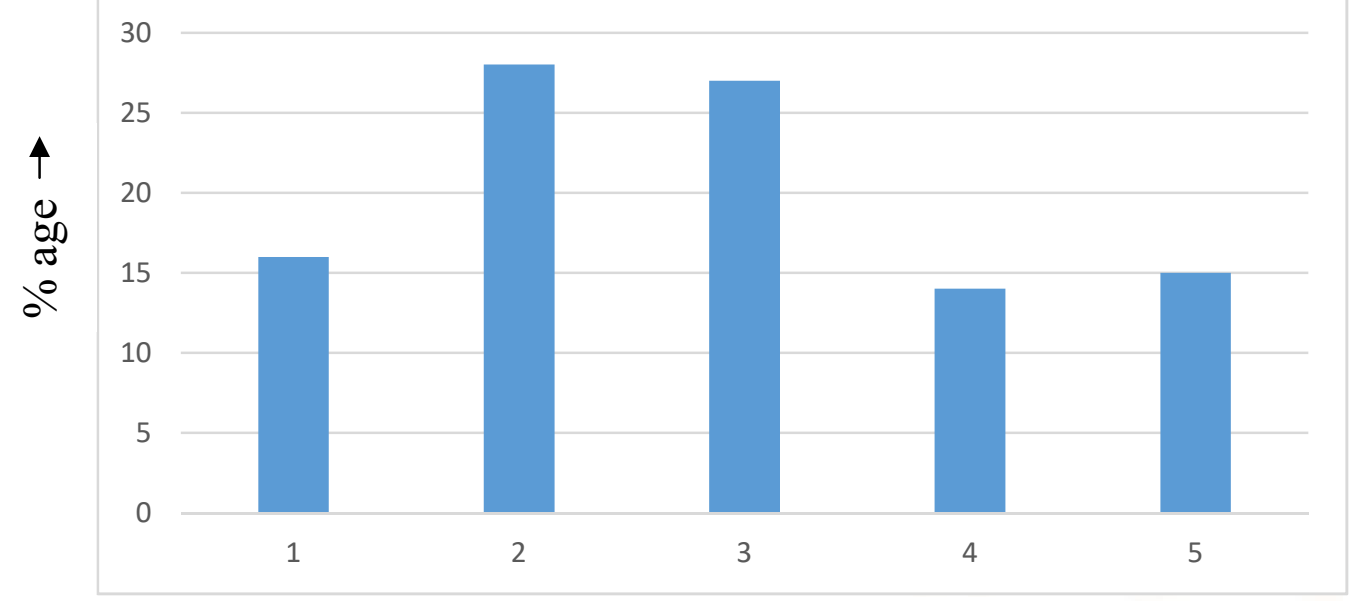

Rating $\rightarrow \quad$ Fig 4.12

- $16 \%$ of the respondents believe that natural forces are a major challenge for the Construction Sector, $27 \%$ of the respondents believe it is a challenge.

Q13: Which of the following Natural forces is major threat for construction industry?

Table 4.13

\begin{tabular}{|l|l|l|}
\hline \multicolumn{3}{|c|}{ Which one of these is a major threat? } \\
\hline A & Flood & 23 \\
\hline B & Earthquake & 3 \\
\hline C & Cyclone & 1 \\
\hline D & All of the above & 73 \\
\hline TOTAL & & 100 \\
\hline
\end{tabular}




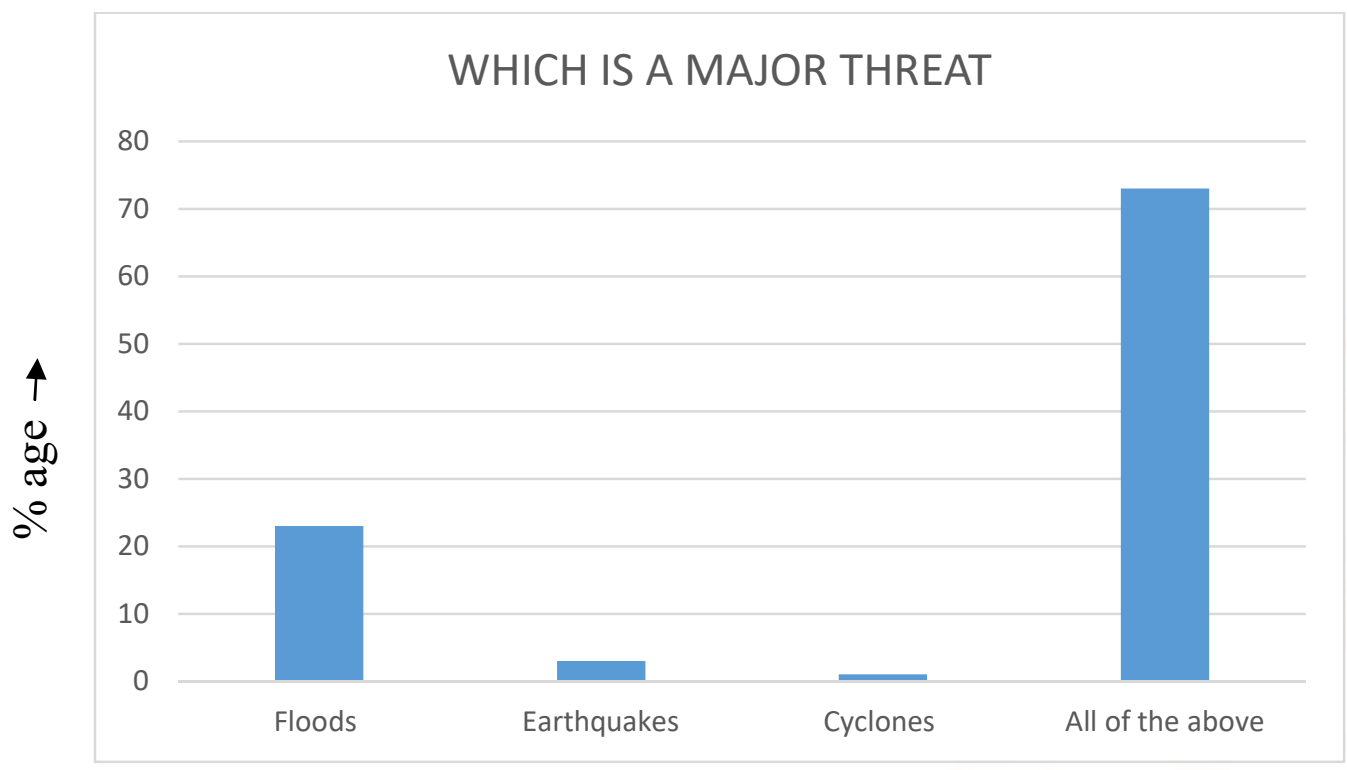

\section{Rating $\rightarrow \quad$ Fig 4.13}

- $73 \%$ of the employees say that floods, earthquakes, cyclones are major threat to construction sector, while $23 \%$ of the employees say only floods is a major threat, $3 \%$ of the employees say only earth quakes are major threat to the industry and $1 \%$ of the employees agree that cyclones are major threat to the industry

\section{Q14: Do you agree that weather conditions affect the construction working?}

Table 4.14

\begin{tabular}{|l|l|}
\hline \multicolumn{2}{|c|}{ Effect of weather conditions on construction } \\
\hline Rating & Response \\
\hline 1 & 17 \\
\hline 2 & 33 \\
\hline 3 & 18 \\
\hline 4 & 12 \\
\hline 5 & 20 \\
\hline Total & 100 \\
\hline
\end{tabular}

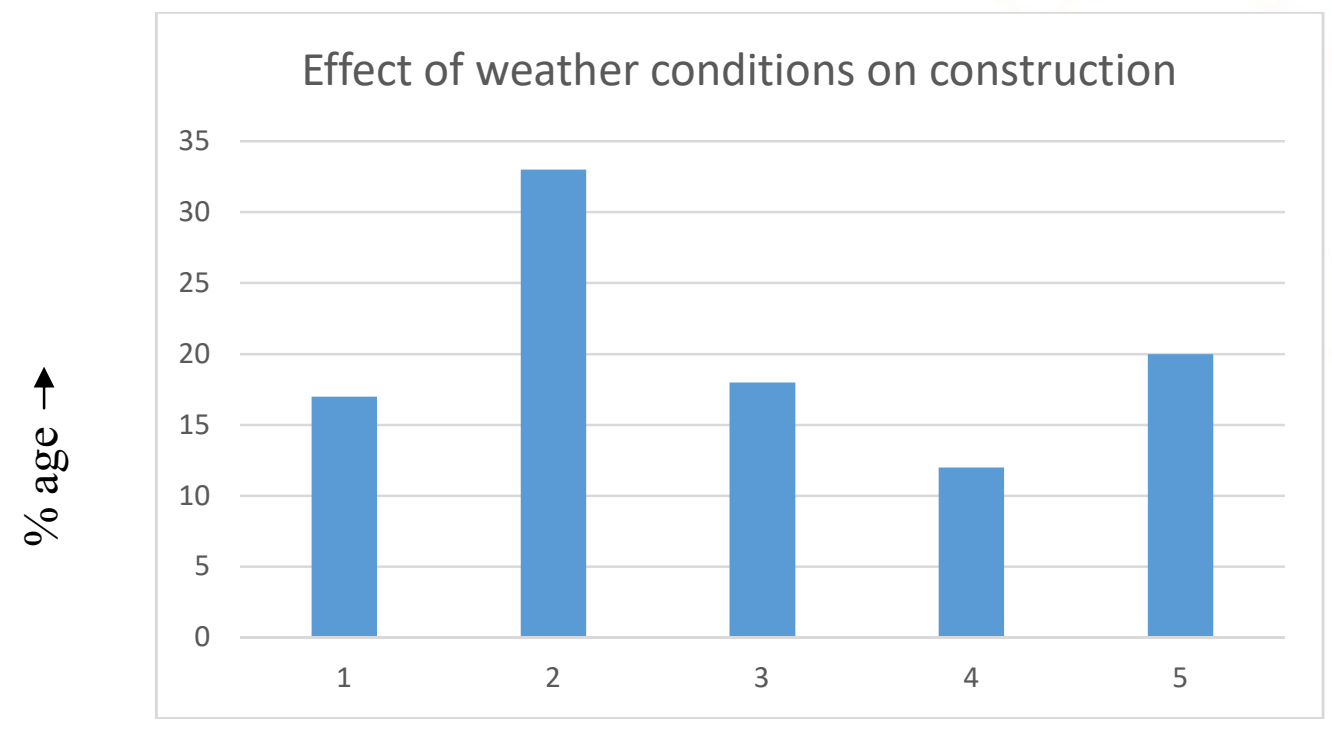

Rating $\rightarrow$ Fig 4.14 
International Journal of Trend in Scientific Research and Development (IJTSRD) ISSN: 2456-6470

- $17 \%$ of the respondents strongly agree that weather conditions affect the construction working, while 33 $\%$ of the respondents agree that weather conditions affect the construction working.

\section{Q15: What kind of importance is given to the formwork structures?}

Table 4.15

\begin{tabular}{|l|l|}
\hline \multicolumn{2}{|c|}{ Importance given to formwork } \\
\hline Rating & Response \\
\hline 1 & 19 \\
\hline 2 & 28 \\
\hline 3 & 20 \\
\hline 4 & 20 \\
\hline 5 & 13 \\
\hline Total & 100 \\
\hline
\end{tabular}

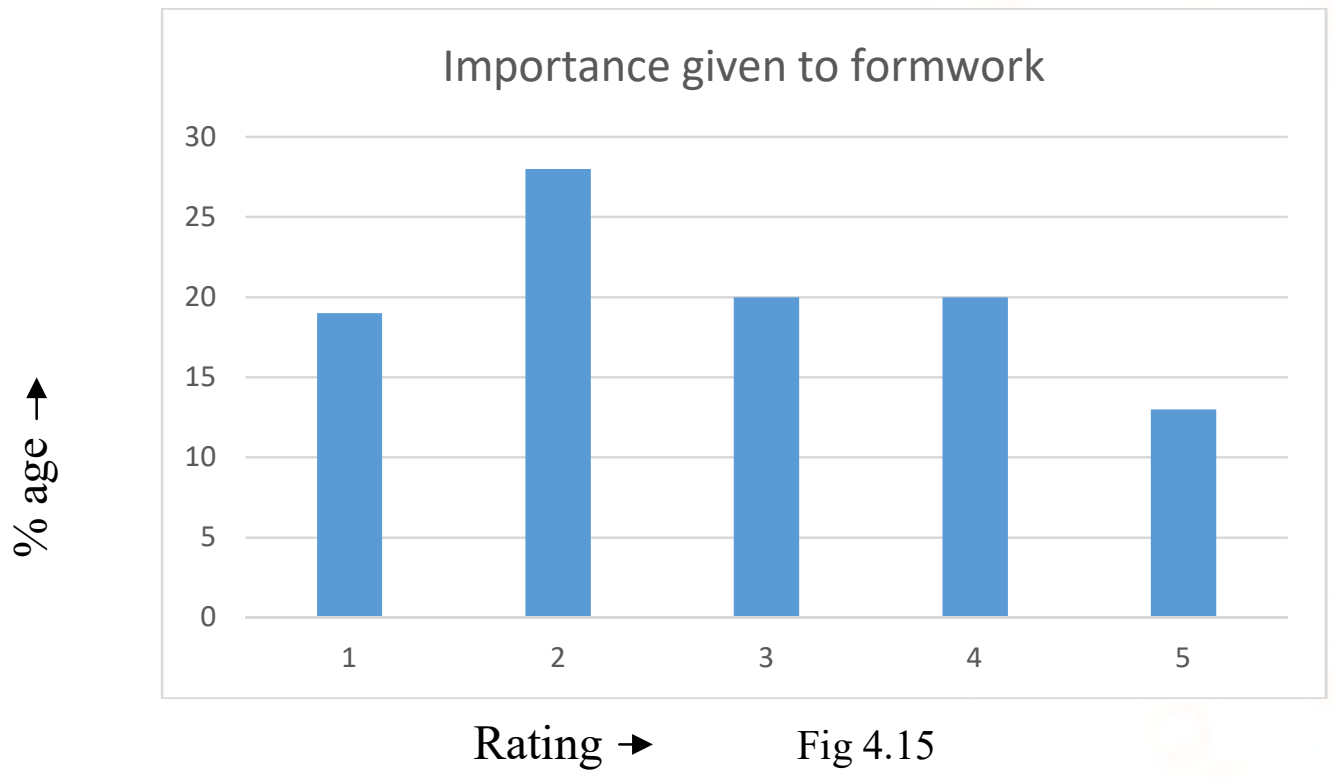

- $19 \%$ of the respondents say that high importance is given to formwork structures, $20 \%$ of the respondents say that average importance is given to formwork structures and $13 \%$ of the respondents say that little importance is given to formwork structures.

Q16: Is there proper safety provisions involved in the execution of formwork structures?

Table 4.16

\begin{tabular}{|l|l|}
\hline \multicolumn{2}{|c|}{ Safety provisions involved in the execution of formwork structures } \\
\hline Rating & Response \\
\hline 1 & 22 \\
\hline 2 & 28 \\
\hline 3 & 23 \\
\hline 4 & 10 \\
\hline 5 & 17 \\
\hline Total & $\mathbf{1 0 0}$ \\
\hline
\end{tabular}




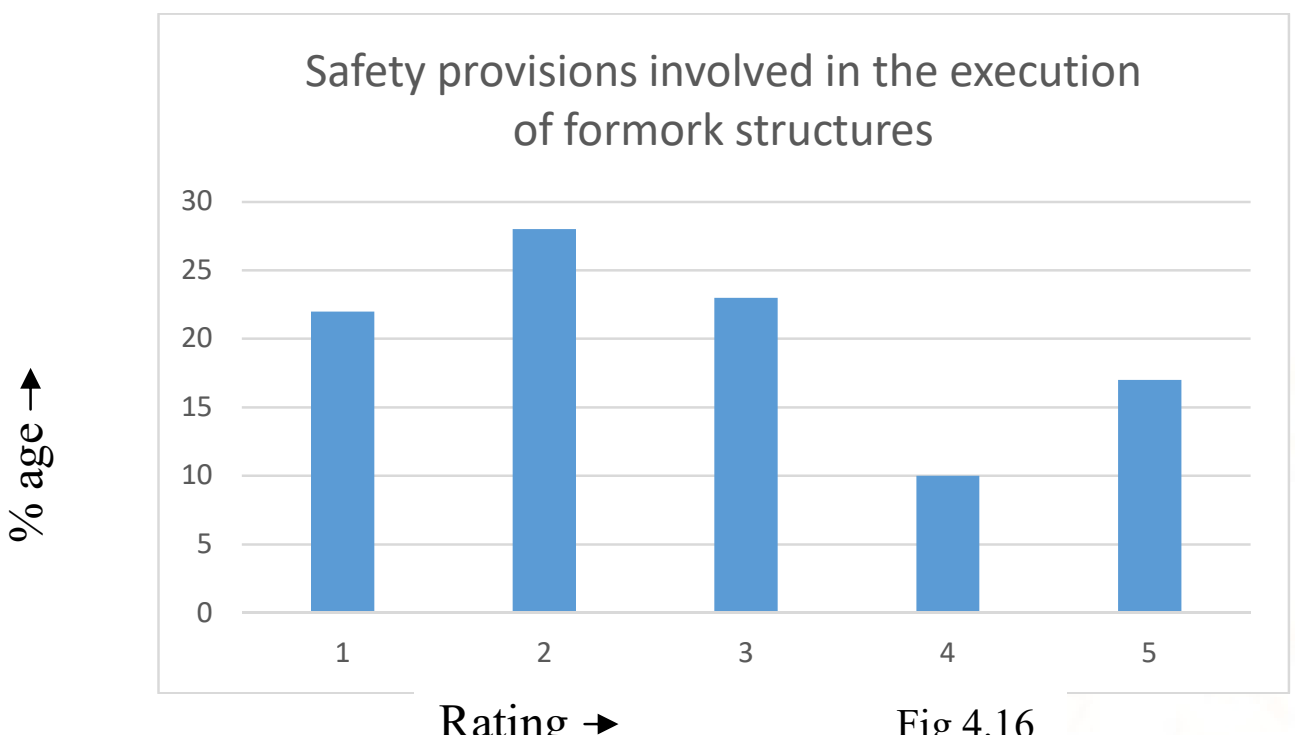

Rating $\rightarrow \quad$ Fig 4.16

- $22 \%$ of the respondents say that there are safety measures are provisioned at site and $17 \%$ of the respondents say that there are not safety provisions at site of construction.

Q17: Are the employees made aware about the safety and safety issues involved at site?

Table 4.17

\begin{tabular}{|l|l|}
\hline \multicolumn{2}{|c|}{ Employees made aware about safety issues } \\
\hline Rating & Response \\
\hline 1 & 18 \\
\hline 2 & 30 \\
\hline 3 & 31 \\
\hline 4 & 16 \\
\hline 5 & 5 \\
\hline Total & 100 \\
\hline
\end{tabular}

Employees made aware about safety issues

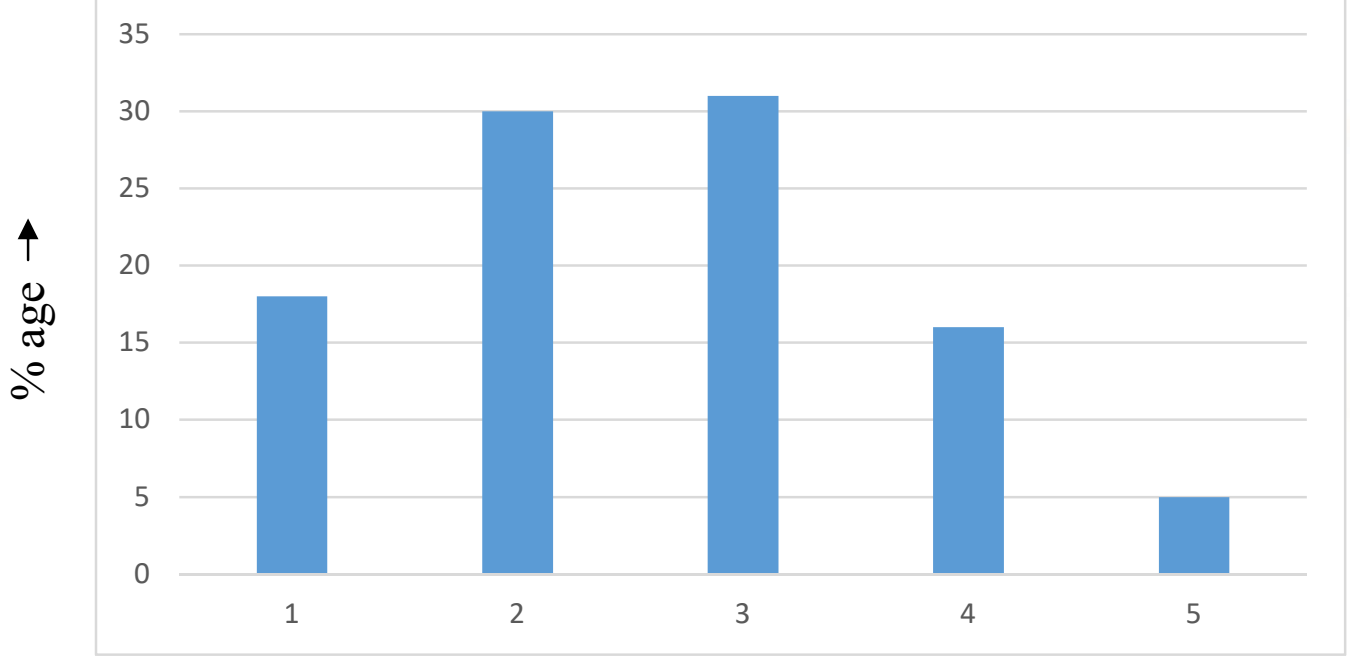

Rating

Fig 4.17 
International Journal of Trend in Scientific Research and Development (IJTSRD) ISSN: 2456-6470

- $18 \%$ of the respondents agree that they are made aware about the safety and safety issues involved while $5 \%$ of the respondents do not agree with this.

\section{Q18: Provision of immediate medical care in case of accidents at site?}

Table 4.18

\begin{tabular}{|l|l|}
\hline \multicolumn{2}{|c|}{ Provision of immediate medical care in case of accidents } \\
\hline Rating & Response \\
\hline 1 & 17 \\
\hline 2 & 38 \\
\hline 3 & 22 \\
\hline 4 & 16 \\
\hline 5 & 7 \\
\hline Total & 100 \\
\hline
\end{tabular}

\section{Provision of immediate medical care in case of} accidents

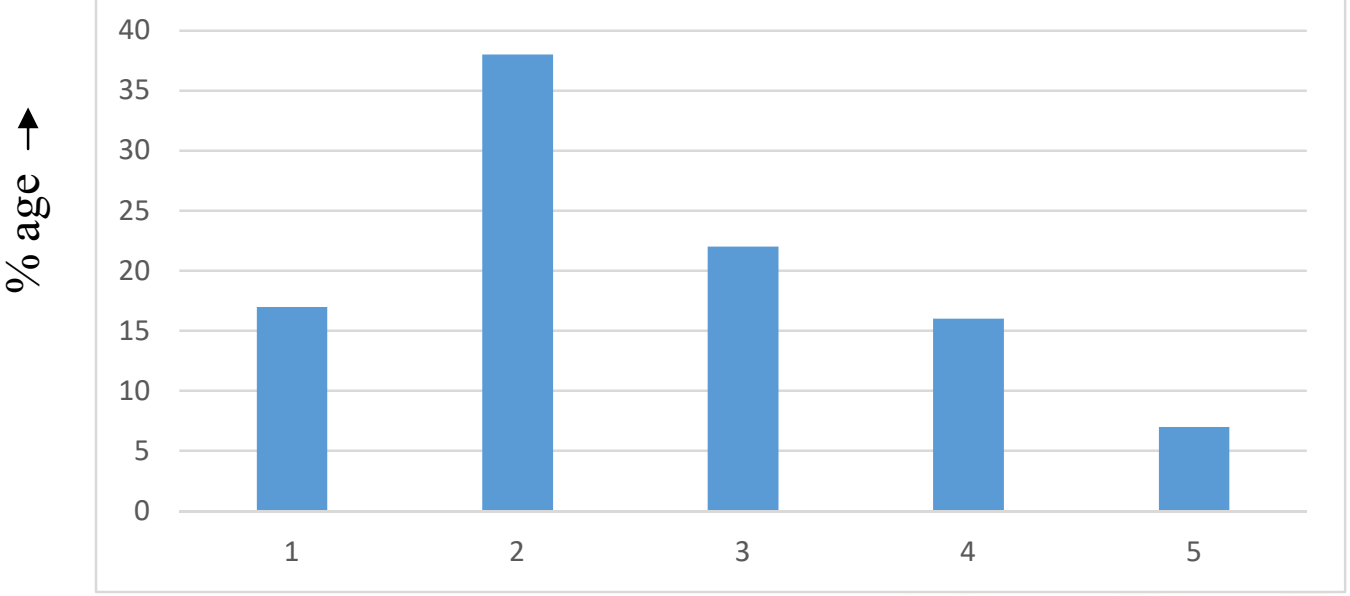

Rating $\rightarrow \quad$ Fig 4.18

$>17 \%$ of the respondents say that there is availability of medical care at site while $7 \%$ of the respondents say that there is not availability of medical care at the site of construction and $22 \%$ had an average opinion.

Q19. Effect of lack of organization in construction industry?

Table 4.19

\begin{tabular}{|l|l|}
\hline \multicolumn{2}{|c|}{ Effect of lack of organization in construction industry } \\
\hline Rating & Response \\
\hline 1 & 14 \\
\hline 2 & 35 \\
\hline 3 & 30 \\
\hline 4 & 12 \\
\hline 5 & 9 \\
\hline Total & 100 \\
\hline
\end{tabular}




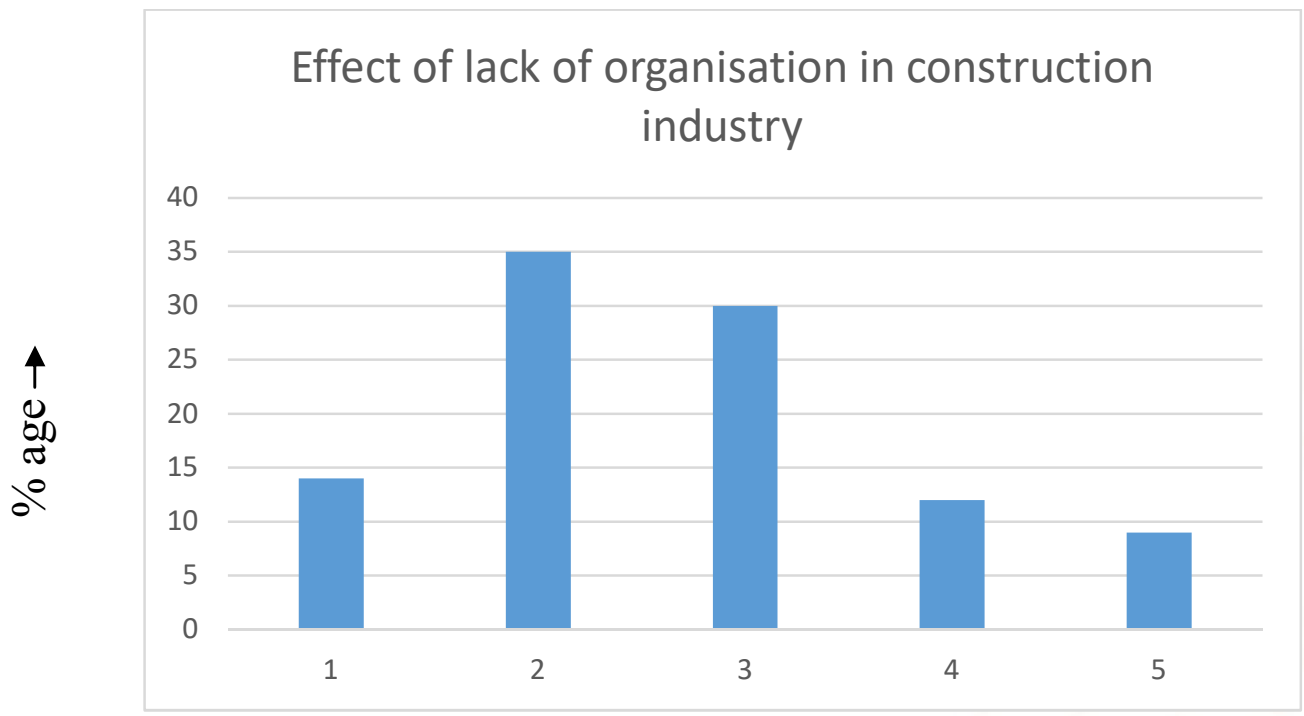

$$
\text { Rating } \rightarrow \quad \text { Fig } 4.19
$$

- $14 \%$ of the respondents say that there is effect of lack of organisation in construction industry while 9 $\%$ of the respondents say that there is not lity of medical care at the site of construction and $30 \%$ had an average opinion.

Q20. How much does the lack of awareness of workers about various safety features affect site working conditions?

Table 4.20

\begin{tabular}{|l|l|}
\hline \multicolumn{2}{|c|}{$\begin{array}{l}\text { Effect of lack of awareness of workers about various safety features on site } \\
\text { working conditions }\end{array}$} \\
\hline Rating & Response \\
\hline 1 & 25 \\
\hline 2 & 34 \\
\hline 3 & 29 \\
\hline 4 & 8 \\
\hline 5 & 4 \\
\hline Total & 100 \\
\hline
\end{tabular}

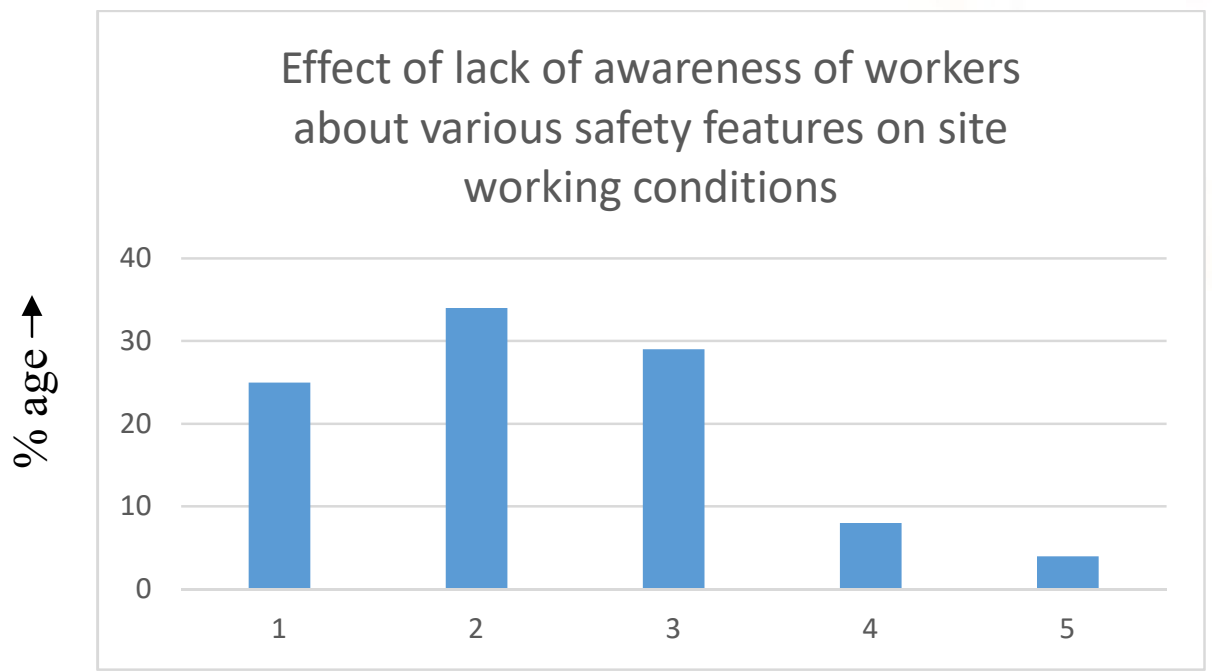

\section{Rating}

Fig 4.20 
International Journal of Trend in Scientific Research and Development (IJTSRD) ISSN: 2456-6470

- $25 \%$ of the respondents say that there is lack of awareness about various safety features on site working conditions while $4 \%$ of the respondents say that there is nolack of awareness about various safety features on site working conditions and $29 \%$ have an average opinion.

\section{Q21. How much does the flow of cash affect the activities on site?}

Table 4.21

\begin{tabular}{|l|l|}
\hline \multicolumn{2}{|c|}{ Effect of flow of cash on various activities on site } \\
\hline Rating & Response \\
\hline 1 & 31 \\
\hline 2 & 24 \\
\hline 3 & 29 \\
\hline 4 & 9 \\
\hline 5 & 7 \\
\hline Total & 100 \\
\hline
\end{tabular}

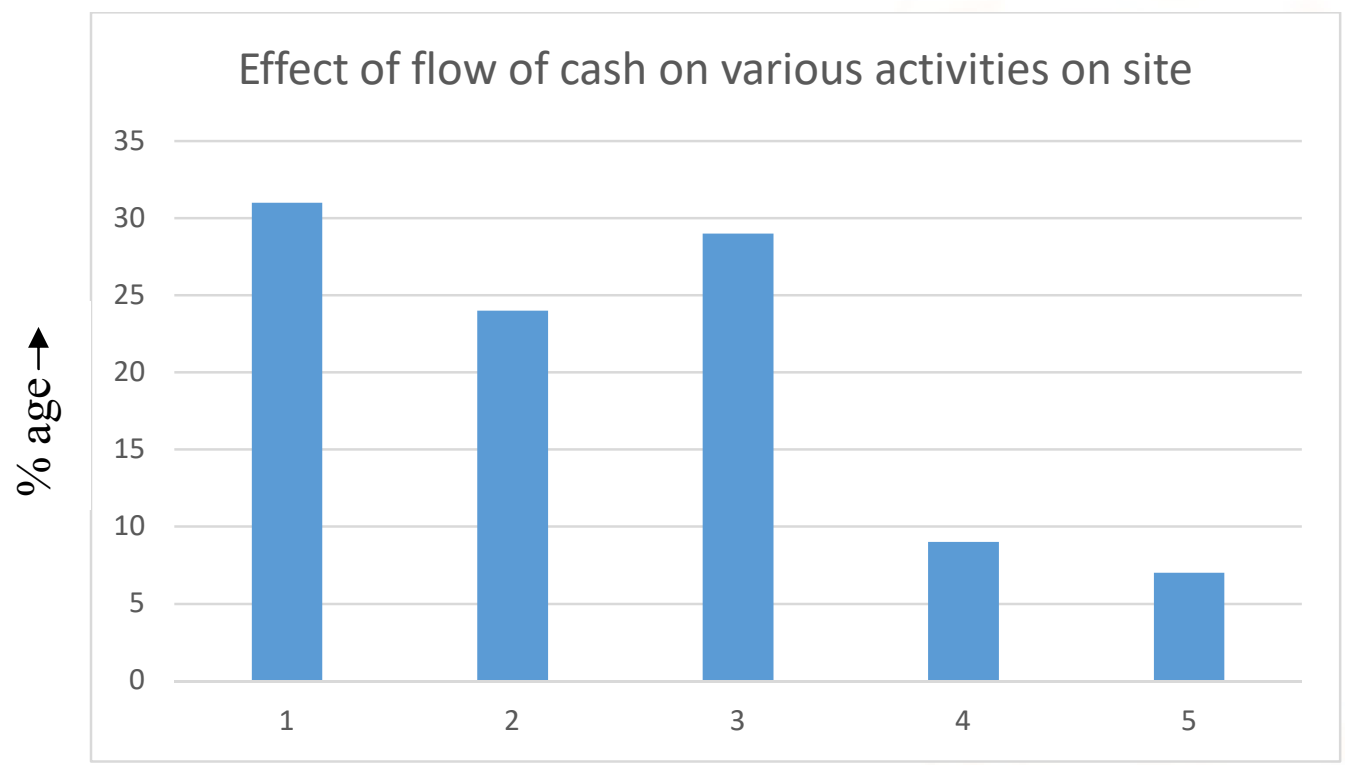

Rating

Fig 4.21

- $31 \%$ of the respondents say that there is effect of flow of cash on various activities on site while $7 \%$ of the respondents say that there is noeffect of flow of cash on various activities on site and $29 \%$ have an average opinion.

\section{Q22. How much does the failure of tools and machines affect work progress?}

Table 4.22

\begin{tabular}{|l|l|}
\hline \multicolumn{2}{|c|}{ Effect of failure of tools and machines on work progress. } \\
\hline Rating & Response \\
\hline 1 & 20 \\
\hline 2 & 37 \\
\hline 3 & 27 \\
\hline 4 & 11 \\
\hline 5 & 5 \\
\hline Total & 100 \\
\hline
\end{tabular}




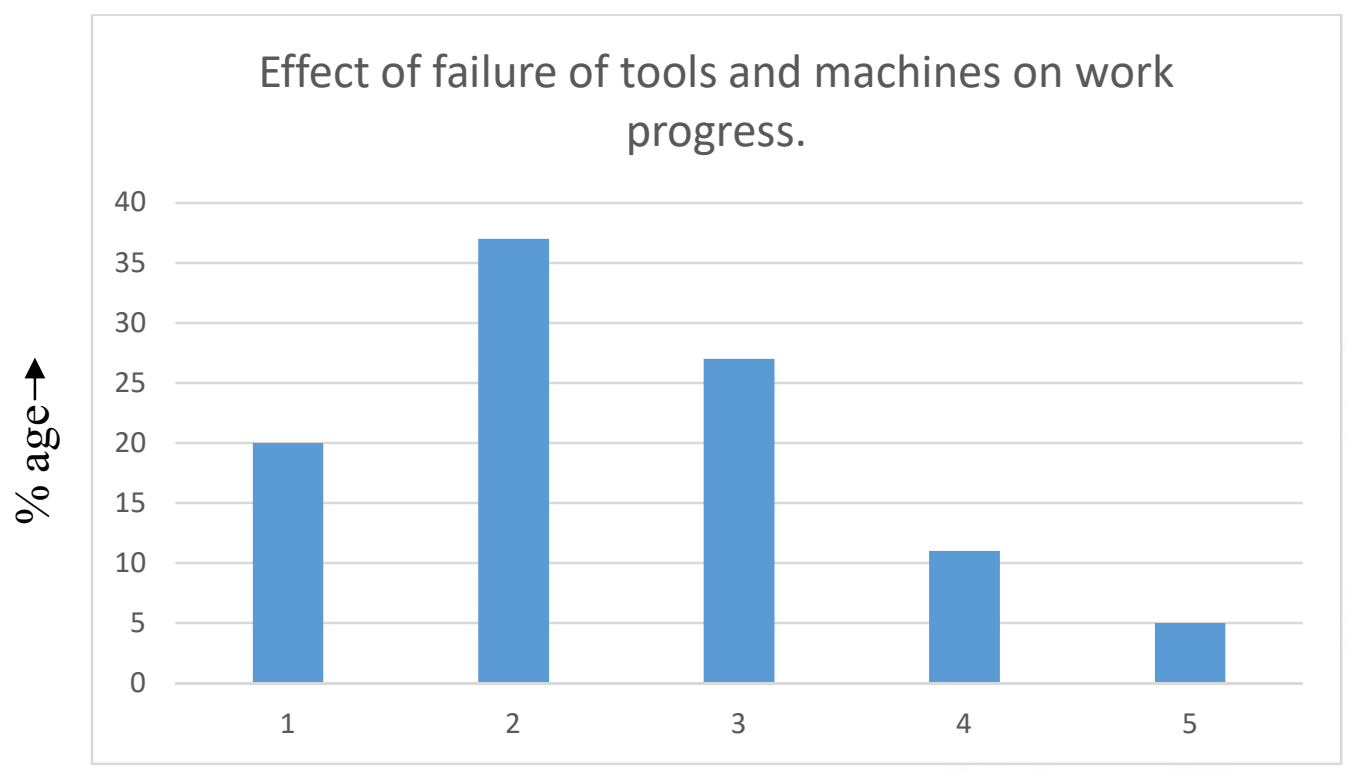

Rating $\rightarrow \quad$ Fig 4.22

- $20 \%$ of the respondents say that there is effect of failure of tools and machines on work progress $5 \%$ of the respondents say that there is no effect of failure of tools and machines on work progress and $27 \%$ have an average opinion.

\section{Q23. How much does public unrest affect site working conditions?}

Table 4.23

\begin{tabular}{|l|l|}
\hline \multicolumn{2}{|c|}{ Effect of public unrest on site working conditions } \\
\hline Rating & Response \\
\hline 1 & 26 \\
\hline 2 & 30 \\
\hline 3 & 21 \\
\hline 4 & 13 \\
\hline 5 & 10 \\
\hline Total & 100 \\
\hline
\end{tabular}

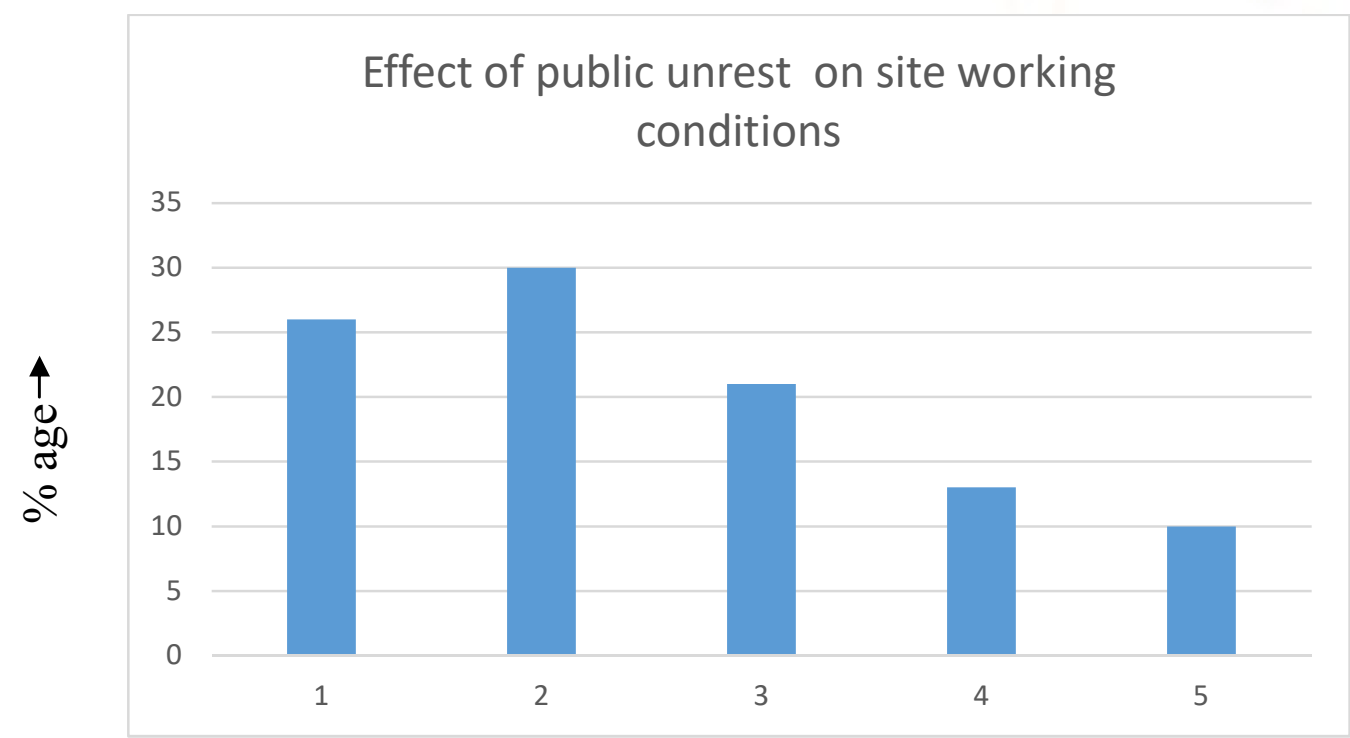

Rating

Fig 4.23 
International Journal of Trend in Scientific Research and Development (IJTSRD) ISSN: 2456-6470

- $26 \%$ of the respondents say that there is effect of public unrest on site working conditions $10 \%$ of the respondents say that there is no effect of public unrest on site working conditions and $21 \%$ have an average opinion.

\section{Q24. How much does deviation from engineering process affect work progress on site?}

Table 4.24

\begin{tabular}{|l|l|}
\hline \multicolumn{2}{|c|}{ Effect of deviation from engineering process on work progress on site. } \\
\hline Rating & Response \\
\hline 1 & 20 \\
\hline 2 & 34 \\
\hline 3 & 24 \\
\hline 4 & 16 \\
\hline 5 & 6 \\
\hline Total & 100 \\
\hline
\end{tabular}

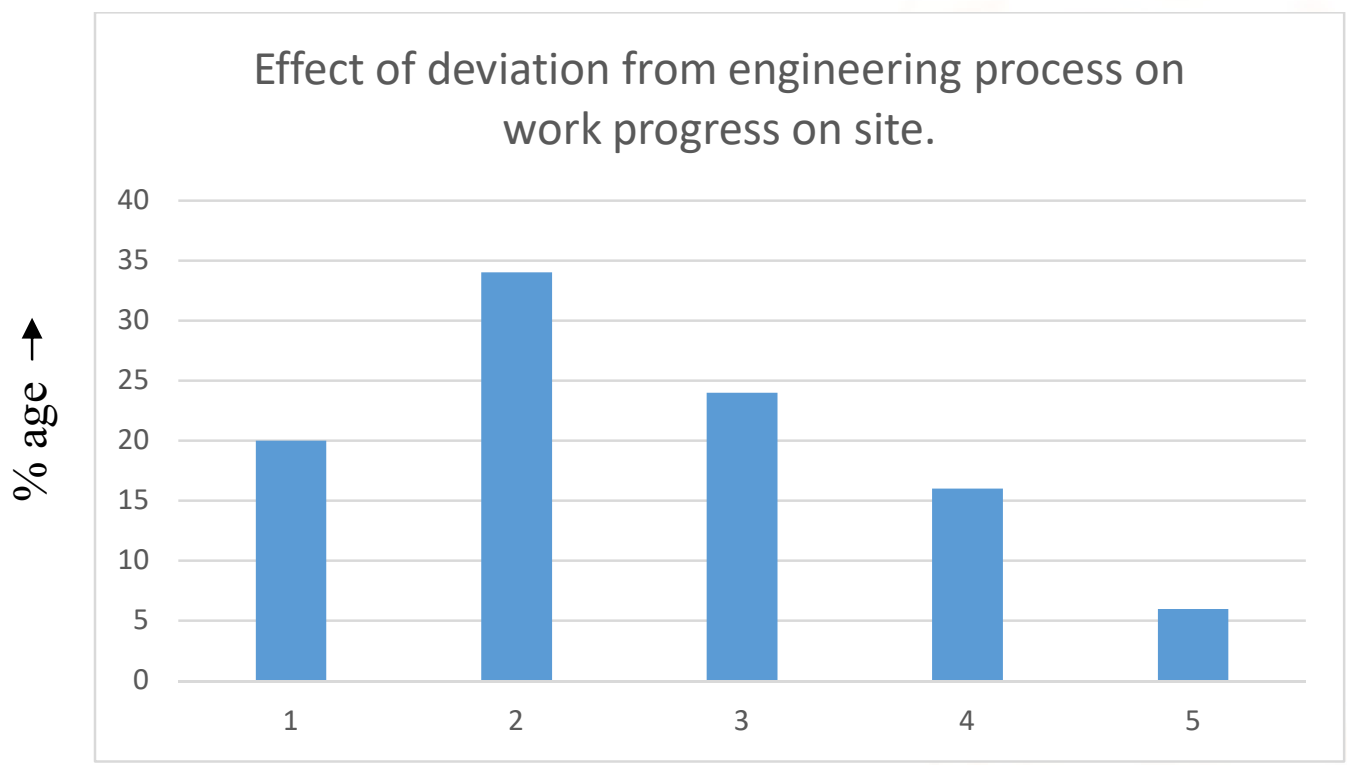

\section{Rating $\rightarrow \quad$ Fig 4.24}

- $20 \%$ of the respondents say that there is effect of deviation from engineering process on work progress on site $6 \%$ of the respondents say that there is no effect from deviation from engineering process on work progress on site and $24 \%$ have an average opinion.

\subsection{Suggestions:}

Table 4.25

CHALLENGES

FACED BY

CONSTRUCTION

SECTOR

Climatic condition

\section{SOLUTION TO OVERCOME THESE CHALLENGES}

The climatic conditions of the region should be studied and the schedule should be prepared according to the climatic condition 


\begin{tabular}{|c|c|}
\hline Labor shortage & $\begin{array}{l}\text { The labors should be brought from nearby areas. They should be treated in good } \\
\text { manner and good accommodation should be provided if labors are not from the } \\
\text { nearby areas }\end{array}$ \\
\hline Material shortage & The organization should increase the material distributers from 2 to 5 \\
\hline Poor workmanship & $\begin{array}{l}\text { The labors should be trained. For important activities only skilled labors should } \\
\text { be used }\end{array}$ \\
\hline $\begin{array}{l}\text { Improper } \\
\text { communication flow }\end{array}$ & $\begin{array}{l}\text { Monthly or weekly meetings should be conducted regularly with the site } \\
\text { engineers and supervisors }\end{array}$ \\
\hline Lack of coordination & Before starting the work for an activity, proper planning should be prepared \\
\hline $\begin{array}{l}\text { Low labor } \\
\text { productivity }\end{array}$ & $\begin{array}{l}\text { Regular inspection should be done and many supervisors should be allocated for } \\
\text { every activity }\end{array}$ \\
\hline Improper scheduling & $\begin{array}{l}\text { The schedule should be prepared with sufficient duration and it should be } \\
\text { prepared by experienced person. The schedule should be prepared with full } \\
\text { details that required to carry over the work without delay }\end{array}$ \\
\hline Illness to labor & $\begin{array}{l}\text { Good hospitality should be provided near the site and free medicines should be } \\
\text { provided by the management and a routine medical checkup should be done }\end{array}$ \\
\hline $\begin{array}{l}\text { Differing } \\
\text { condition }\end{array}$ & The site condition should be studied in detail before the start of the work \\
\hline Third party & $\begin{array}{l}\text { Penalty should be given for the delay of work done for the sub-contractors so that } \\
\text { the sub-contractor(Third party) will not make any delay of work again }\end{array}$ \\
\hline
\end{tabular}

\section{REFERENCES}

Abdel-Razek, R.H. (1998), "Factors affecting construction quality in Egypt: identification andrelative importance", Engineering, Construction and

Architectural Management, Vol. 5No. 3, pp. 220227.

$>$ Satyanarayana, K.N. and Iyer, K.C. (1996), "Evaluation of Delays in Indian construction contracts", Journal of the Institution of Engineers (India), Vol. 77 No. 2, pp. 14-22.

Tabish, S. and Jha, K. (2011), "Analyses and evaluation of irregularities in public procurement in India", Construction Management and Economics, Vol. 29 No. 3, pp. 261-274.
Turin, D.A. (1973), “ The Construction Industry: Its Economic Significance and Its Role in Development", University College Environmental Research Group, London.

Arditi, D. and Gunayadin, M. H. (1998), Total quality management in theconstruction process, International Journal of Project Management Vol. 15 , No.4, pp. $235-243$ 